Original article

\title{
Comparison between the three porcine RN genotypes for growth, carcass composition and meat quality traits
}

\author{
Pascale Le RoY ${ }^{a *}$, Jean-Michel ELSEN ${ }^{\mathrm{b}}$, Jean-Claude CARITEZ ${ }^{\mathrm{c}}$, \\ André TALMANT ${ }^{d}$, Hervé JUIN ${ }^{c}$, Pierre SELliER ${ }^{\mathrm{a}}$, \\ Gabriel MONIN ${ }^{\mathrm{d}}$ \\ a Station de génétique quantitative et appliquée, \\ Institut national de la recherche agronomique, \\ 78352 Jouy-en-Josas Cedex, France \\ b Station d'amélioration génétique des animaux, \\ Institut national de la recherche agronomique, \\ BP 27, 31326 Castanet Tolosan cedex, France \\ ${ }^{\mathrm{c}}$ Domaine du Magneraud, \\ Institut national de la recherche agronomique, \\ 17700 Surgères, France \\ d Station de recherches sur la viande, \\ Institut national de la recherche agronomique, Theix, \\ 63122 Saint-Genès-Champanelle, France
}

(Received 5 October 1999; accepted 10 January 2000)

\begin{abstract}
A three-step experimental design has been carried out to add evidence about the existence of the $\mathrm{RN}$ gene, with two segregating alleles $\mathrm{RN}^{-}$and $\mathrm{rn}^{+}$, having major effects on meat quality in pigs, to estimate its effects on production traits and to map the RN locus. In the present article, the experimental population and sampling procedures are described and discussed, and effects of the three RN genotypes on growth and carcass traits are presented. The RN genotype had no major effect on growth performance and killing out percentage. Variables pertaining to carcass tissue composition showed that the $\mathrm{RN}^{-}$allele is associated with leaner carcasses (about 1 s.d. effect without dominance for back fat thickness, 0.5 s.d. effect with dominance for weights of joints). Muscle glycolytic potential (GP) was considerably higher in $\mathrm{RN}^{-}$carriers, with a maximum of a 6.85 s.d. effect for the live longissimus muscle GP. Physico-chemical characteristics of meat were also influenced by the RN genotype in a dominant way, ultimate $\mathrm{pH}$ differing by about 2 s.d. between homozygous genotypes and meat colour by about 1 s.d. Technological quality was also affected, with a 1 s.d.
\end{abstract}

* Correspondence and reprints

E-mail: leroy@dga.jouy.inra.fr 
decrease in technological yield for $\mathrm{RN}^{-}$carriers. The $\mathrm{RN}$ genotype had a more limited effect on eating quality. On the whole, the identity between the acid meat condition and the $\mathrm{RN}^{-}$allele effect is clearly demonstrated (higher muscle GP, lower ultimate $\mathrm{pH}$, paler meat and lower protein content), and the unfavourable relationship between GP and carcass lean to fat ratio is confirmed.

pig / major gene / RN gene / meat quality / carcass composition

Résumé - Comparaison des trois génotypes RN chez le porc pour les caractères de croissance, de composition de la carcasse et de qualité de la viande. Un protocole expérimental en trois étapes a été mis en œuvre pour confirmer l'existence du gène $\mathrm{RN}$, avec deux allèles en ségrégation $\mathrm{RN}^{-}$et $\mathrm{rn}^{+}$, à effet majeur sur la qualité de la viande chez le porc, en estimer les effets sur les caractères de production et en déterminer la localisation génétique. Dans cet article, la population expérimentale et les procédures d'échantillonnage sont décrites et discutées, puis les effets des trois génotypes RN sur les caractères de croissance et carcasse sont présentés. Le génotype RN n'a pas d'effet notable sur les performances de croissance et le rendement de carcasse. Les variables relatives à la composition tissulaire de la carcasse indiquent que l'allèle $\mathrm{RN}^{-}$est associé à des carcasses plus maigres (environ 1 écart type sans dominance pour les épaisseurs de lard dorsal, 0,5 e.t. avec dominance pour les poids de morceaux). Le potentiel glycolytique musculaire (GP) est beaucoup plus élevé chez les porteurs de $\mathrm{RN}^{-}$, avec un écart maximum de 6,85 e.t. pour la mesure in vivo du GP sur le muscle longissimus. Les caractéristiques physico-chimiques de la viande sont également influencées par le génotype $\mathrm{RN}$ d'une façon non additive, le $\mathrm{pH}$ ultime différant d'environ 2 e.t. entre homozygotes et la couleur de la viande d'environ 1 e.t. La qualité technologique est aussi affectée, avec 1 e.t. de diminution du rendement technologique chez les porteurs de $\mathrm{RN}^{-}$. Le génotype au locus $\mathrm{RN}$ a un effet plus limité sur les qualités sensorielles de la viande. Globalement, l'identité entre les caractéristiques de la viande acide et les effets de l'allèle $\mathrm{RN}^{-}$est clairement démontrée (potentiel glycolytique musculaire supérieur, $\mathrm{pH}$ ultime inférieur, viande plus pâle, concentration en protéines inférieure) et la relation défavorable entre GP et rapport muscle/gras est confirmée.

porc / gène majeur / gène RN / qualité de la viande / composition de la carcasse

\section{INTRODUCTION}

Pigs showing an abnormally large extent of post mortem muscle $\mathrm{pH}$ fall were first described by Monin and Sellier [26] as characteristic of the Hampshire breed (i.e. "Hampshire effect"). In 1986, Naveau [28] postulated the existence of a single major gene to explain the occurrence of this "acid meat" condition in two composite lines, Penshire and Laconie, built from Hampshire blood at a rate of $1 / 2$ and $1 / 3$, respectively. In the latter study, the genetic determination of an indicator of the technological yield of cured-cooked ham processing, the "Napole yield" (RTN: Rendement Technologique Napole [29]), was explored. The postulated major gene was called $\mathrm{RN}$, the dominant allele responsible for the decrease of RTN being $\mathrm{RN}^{-}$and the normal recessive allele being $\mathrm{rn}^{+}$. This hypothesis was further confirmed by Le Roy et al. [20] using segregation analysis methods on RTN field data. Moreover, Wassmuth et al. [35], analysing Hampshire crossbred populations, demonstrated the segregation of a major gene (denoted HF for "Hampshirefaktor") influencing meat quality in the same way as RN. However, all these results were obtained from a posteriori statistical analyses of field data and had to be confirmed using an experimental design specifically devoted to the evaluation of RN gene effects. 
It was early postulated that the "Hampshire effect" arises from higher muscle glycolytic potential (GP) $[11,26]$. That the primary effect of the $\mathrm{RN}^{-}$allele is to strongly increase GP was a logical and attractive hypothesis. Several studies have therefore consisted of comparing animals of either high GP or low GP, within Hampshire crossbred populations, in order to estimate the effects of the $\mathrm{RN}^{-}$allele $[7-10,23,24,30]$. However, this classification based on GP is not fully satisfying because (1) the RN gene was initially found through its effect on RTN, and the effect of the $\mathrm{RN}^{-}$allele on GP has never been properly demonstrated, (2) only $\mathrm{RN}^{-}$carriers and non-carriers have been compared instead of the three genotypes $\mathrm{RN}^{-} / \mathrm{RN}^{-}, \mathrm{RN}^{-} / \mathrm{rn}^{+}$and $\mathrm{rn}^{+} / \mathrm{rn}^{+}$, and (3) estimates of the $\mathrm{RN}^{-}$effect could be biased due to the selection procedure which led to comparison of animals with extreme GP phenotypes and thus potentially extreme values for correlated traits.

A three-step experimental design has been implemented to add evidence about the existence of the RN gene [21], to estimate its effects on various traits while avoiding the above-mentioned drawbacks, and to map the RN locus [25]. The aim of the present article is: (1) to describe the experimental population; (2) to give elements for validation of the comparison between $\mathrm{RN}$ genotypes; (3) to report the effects of the three RN genotypes on the three main traits characterising the Hampshire effect and the acid meat condition (RTN, GP and ultimate $\mathrm{pH}$ ), as well as on growth performance and carcass quality. Results concerning the effects of the three RN genotypes on chemical composition, enzyme activities and myofiber characteristics of muscle are reported elsewhere [19].

\section{MATERIALS AND METHODS}

\subsection{Experimental design}

\subsubsection{General principles}

The experiment was carried out on Le Magneraud INRA Unit (Surgères, Charente Maritime, France). Founder animals were from the Laconie composite line, created in 1973 and selected by the Pen ar Lan breeding company (Maxent, Ille et Vilaine, France). This line was originally founded with Hampshire, Piétrain and Large White blood in equal proportions. The present design was primarily constructed to compare the three RN genotypes and was set up according to three principles: (1) comparisons had to be made between individuals differing by their $\mathrm{RN}$ genotype but sharing similar polygenic background; (2) the RN genotype had to be determined using the initial definition of the gene, i.e. its effect on the RTN trait; and (3) the effects of the RN genotype had to be measured on animals of a priori known genotypes, i.e. animals born from proven homozygous parents.

The design comprised three steps: (1) animals supposed to be heterozygous were intercrossed to produce a segregating population of $\mathrm{RN}^{-} / \mathrm{RN}^{-}, \mathrm{RN}^{-} / \mathrm{rn}^{+}$ and $\mathrm{rn}^{+} / \mathrm{rn}^{+}$individuals sharing similar polygenic background; (2) males and females from this segregating population were progeny tested with the aim of determining their RN genotype; (3) offspring from proven homozygous parents were produced in a "diallel" cross for comparing the three RN genotypes. 


\subsubsection{Herd foundation}

Prior to the start of this experiment, RTN had been recorded on 9726 Laconie animals (from 156 sires and 937 dams) and all corresponding breeding boars and sows were genotyped for RN from analysing RTN records of their progeny. Simplified segregation analysis as described by Elsen and Le Roy [6] was used assuming segregation of the two alleles $\mathrm{RN}^{-}$and $\mathrm{rn}^{+}$in both sexes. Boars and sows having an estimated probability of 1 to be homozygous (either $\mathrm{rn}^{+} / \mathrm{rn}^{+}$or $\mathrm{RN}^{-} / \mathrm{RN}^{-}$) were chosen to establish the experimental population. The consistency of predicted genotypes of parents, mates and grand parents was checked prior to the final choice. Five females classified as $\mathrm{RN}^{-} / \mathrm{RN}^{-}$and 4 females classified as $\mathrm{rn}^{+} / \mathrm{rn}^{+}$were mated to 6 males classified as $\mathrm{rn}^{+} / \mathrm{rn}^{+}$, and pregnant sows were transferred to Le Magneraud where they farrowed. Two groups of piglets from the resulting litters were considered: (1) a group of animals born from $\mathrm{rn}^{+} / \mathrm{rn}^{+}$dams, assumed to be homozygous $\mathrm{rn}^{+} / \mathrm{rn}^{+}$, and among which 4 males and 8 females were used to found a tester line $(\mathrm{T}) ;(2)$ a group of animals born from $\mathrm{RN}^{-} / \mathrm{RN}^{-}$dams, assumed to be heterozygous $\mathrm{RN}^{-} / \mathrm{rn}^{+}$, and among which 6 males and 19 females were used to found the segregant population $(\mathrm{S})$.

\subsubsection{Progeny test}

These 6 sires and 19 dams gave birth to 273 candidate offspring among which $\mathrm{RN}^{-} / \mathrm{RN}^{-}, \mathrm{RN}^{-} / \mathrm{rn}^{+}$and $\mathrm{rn}^{+} / \mathrm{rn}^{+}$were expected in proportions $1 / 4,1 / 2$ and $1 / 4$, respectively. Due to limited experimental facilities, a small part of these candidates could be progeny tested for RTN. In order to avoid a random loss of homozygotes, preselection of the animals to be progeny-tested was performed on the basis of an individual in vivo measurement of muscle GP (IVGP) at $70 \mathrm{~kg}$ live weight [34]. Thus, among 67 boars and 83 gilts measured for IVGP, 16 and 43 were kept for being submitted to the progeny test, 6 and 12 with low IVGP (lower than $200 \mu \mathrm{mol} \cdot \mathrm{g}^{-1}$, a priori $\mathrm{rn}^{+} / \mathrm{rn}^{+}$) and 10 and 31 with high IVGP (greater than $300 \mu \mathrm{mol} \cdot \mathrm{g}^{-1}$, a priori $\mathrm{RN}^{-} / \mathrm{RN}^{-}$or $\mathrm{RN}^{-} / \mathrm{rn}^{+}$). The $\mathrm{T}$ line, supposed to be homozygous recessive $\mathrm{rn}^{+} / \mathrm{rn}^{+}$, consisted of 6 sires and 34 dams. In order to verify the RN genotype of these animals, a progeny test was also implemented, with each $\mathrm{T}$ dam giving one litter sired by a $\mathrm{T}$ boar.

A segregation analysis was performed on the progeny-test RTN data [21] to estimate the posterior genotype probabilities of all sires and dams (Fig. 1). Results showed that one T boar was certainly heterozygous. As a consequence, the litters sired by this boar were deleted from the design, and only 37 of the 43 females from the $\mathrm{S}$ population were validly tested. From both groups of $\mathrm{S}$ animals classified as homozygous $\left(\mathrm{RN}^{-} / \mathrm{RN}^{-}\right.$or $\left.\mathrm{rn}^{+} / \mathrm{rn}^{+}\right), 3$ boars and 11 sows were kept to generate the animals of the third step.

\subsubsection{Diallel cross}

The 22 sows were distributed in three 3 -week-spaced farrowing batches. One of the $\mathrm{rn}^{+} / \mathrm{rn}^{+}$dams gave no litter, 7 dams $\left(5 \mathrm{rn}^{+} / \mathrm{rn}^{+}\right.$and $\left.2 \mathrm{RN}^{-} / \mathrm{RN}^{-}\right)$ gave only one litter, and the 14 others gave 2 litters, with alternate genotypes for 10 of them, i.e. one heterozygous litter and one homozygous litter. Finally, 12, 11 and 12 litters were produced in the $\mathrm{RN}^{-} / \mathrm{RN}^{-}, \mathrm{RN}^{-} / \mathrm{rn}^{+}$and $\mathrm{rn}^{+} / \mathrm{rn}^{+}$ 
genotypes, respectively and it was possible to balance the distribution of RN genotypes within each slaughter series. Numbers of pigs recorded for each group of traits are given by RN genotype in Table I.

Table I. Numbers of pigs recorded for each group of traits.

\begin{tabular}{lccc}
\hline & \multicolumn{3}{c}{$\mathrm{RN}$ genotype } \\
\cline { 2 - 4 } Trait & $\mathrm{RN}^{-} / \mathrm{RN}^{-}$ & $\mathrm{RN}^{-} / \mathrm{rn}^{+}$ & $\mathrm{rn}^{+} / \mathrm{rn}^{+}$ \\
\hline $\begin{array}{l}\text { Postweaning growth } \\
\text { performance }\end{array}$ & 103 & 92 & 69 \\
\hline $\begin{array}{l}\text { In vivo muscle glycolytic potential } \\
(11)\end{array}$ & 98 & $(11)$ & $(9)$ \\
\hline $\begin{array}{l}\text { Carcass composition, Napole yield } \\
\text { and physico-chemical muscle } \\
\text { characteristics }\end{array}$ & 90 & 73 & 66 \\
\hline $\begin{array}{l}\text { Loin eye area, pH } \\
\text { glycolytic potential and cured-cooked } \\
\text { ham processing ability }\end{array}$ & 37 & 38 & 39 \\
\hline \begin{tabular}{l} 
Eating quality of meat \\
\hline
\end{tabular} & 17 & & \\
\hline
\end{tabular}

(1) In brackets, numbers of pens.

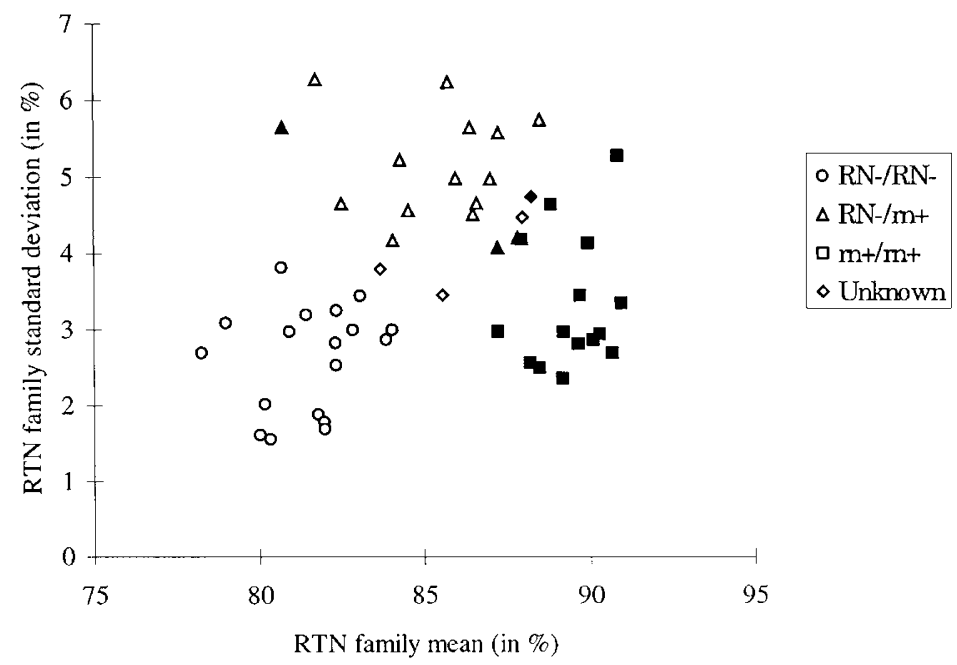

Figure 1. Results of the progeny test for RTN: relationships of RN genotype estimated by segregation analysis with family mean, within family standard deviation and own IVGP value (in white, parents with IVGP greater than $300 \mu \mathrm{mol} \cdot \mathrm{g}^{-1}$; in black, parents with IVGP smaller than $\left.200 \mu \mathrm{mol} \cdot \mathrm{g}^{-1}\right)$. 


\subsection{Traits}

\subsubsection{Growth performance}

Piglets were weaned at 28 days of age and moved to the fattening building at 77 days. They were penned in groups of 6 to 12 animals, each pen including females or castrated males from the same RN genotype. During the fattening period, animals were fed ad libitum a standard pelleted diet (crude protein: 17.0\%; crude fat: 1.5\%; crude fiber: 4.5\%; ash: 6.8\%; lysine: 0.85\%; ME: 3091 $\left.\mathrm{kcal} \cdot \mathrm{kg}^{-1}\right)$. Average daily gain was recorded individually from 30 to $100 \mathrm{~kg}$ live weight. Food conversion ratio from 30 to $100 \mathrm{~kg}$ live weight was calculated on a pen basis as the ratio of feed consumed to live weight gain.

\subsubsection{Live muscle glycolytic potential}

A shot-biopsy sample of longissimus lumborum muscle was taken at $71 \pm$ $7 \mathrm{~kg}$ live weight, as described by Talmant et al. [34]. Biopsy samples were immediately trimmed of skin and fat, and homogenised in $10 \mathrm{~mL}$ of 0.55 $\mathrm{M}$ perchloric acid. At the laboratory (Station de recherches sur la viande, INRA, Theix, France), $0.5 \mathrm{~mL}$ of the homogenate was used for simultaneous determination of glycogen, glucose-6-phosphate and glucose [5]. The rest of the homogenate was centrifuged at $2500 \times g$ during $10 \mathrm{~min}$, and the supernatant was used for lactate determination [2]. Muscle GP, in $\mu$ mol equivalent lactate per $\mathrm{g}$ of fresh tissue, was calculated according to Monin and Sellier [26]: GP $=2([$ glycogen $]+$ [glucose-6-phosphate $]+$ [glucose $])+$ [lactate $]$. The sum of glycogen, glucose-6-phosphate and glucose concentrations will be referred to as "glycogen concentration" in the following.

\subsubsection{Carcass composition}

Pigs were slaughtered at $107 \pm 9 \mathrm{~kg}$ live weight in a commercial abattoir (Celles sur Belle, Charente Maritime, France). On the day after slaughter, the carcass (with head, feet and leaf fat) was weighed, and killing out percentage was calculated as the ratio of cold carcass weight to live weight. Carcass length (from the first cervical vertebra to the anterior edge of the pubial symphysis) and midline back fat thickness (at the shoulder, back and rump levels) were measured on the right side of the carcass. Then, this side was weighed and divided into seven joints (ham, loin, shoulder, belly, back fat, leaf fat and feet) according to a standardised cutting method [1]. Weights of joints were recorded and carcass lean percentage (CLP) was estimated according to the following equation (1): CLP $=-42.035+(1.282$ ham weight +1.818 loin weight +0.616 shoulder weight +0.701 belly weight +0.040 leaf fat weight -0.678 back fat weight) / half carcass weight. Carcass compactness was defined as the ratio of loin weight to carcass length. Loin eye area was measured at the last rib level by planimetry using a tablet digitizer (Hitachi).

\subsubsection{Physico-chemical characteristics of muscle}

At 35 min after slaughter, a sample of longissimus muscle was removed from the right half-carcass at the last rib level and homogenised in $18 \mathrm{~mL}$ of $5 \mathrm{mM}$ iodoacetate for $\mathrm{pH}$ measurement $(\mathrm{pH} 1)$. At the same time, samples of three 
muscles, differing in their metabolic and contractile properties (longissimus, semimembranosus and semispinalis capitis) [16,27], were taken for determination of post mortem glycogen concentration, lactate concentration and GP (PMGP), as previously described.

The day after slaughter, the following traits were recorded on loins and hams:

- $\mathrm{pH}_{24}$ of adductor femoris, biceps femoris, gluteus superficialis, longissimus, semimembranosus and semispinalis capitis muscles. Measurements were made directly on muscles using a combined glass electrode (Ingold, Mettler Toledo, Switzerland) and a portable pHmeter (CG818, Schott Gerät, Germany);

- colour ( $\mathrm{L}^{*}, \mathrm{a}^{*}$ and $\mathrm{b}^{*}$ values) of biceps femoris, gluteus superficialis and longissimus muscles, using a Minolta chromameter CR-300;

- water-holding capacity of biceps femoris, gluteus superficialis and longissimus muscles, as assessed by the "filter paper imbibition time" method [3], i.e. the time required for complete wetting of a $1 \mathrm{~cm}^{2}$ filter paper piece put on the freshly cut surface of the muscle.

\subsubsection{Technological meat quality}

The "Napole" curing-cooking yield was recorded on a $100 \mathrm{~g}$ sample of semimembranosus muscle. The method used was that described by Naveau et al. [29] except that the muscle sample was removed from the right half-carcass the day after slaughter and not on the slaughter line. However, the time of meat maturation at $4{ }^{\circ} \mathrm{C}$, about $24 \mathrm{~h}$, remained the same. One ham was processed into cured-cooked ham by the Eden company (La Chataîgneraie, Vendée, France). Raw weight $\left(X_{1}\right)$, deboned-defatted weight $\left(X_{2}\right)$, weight after curing $\left(X_{3}\right)$ and weight after cooking $\left(X_{4}\right)$ were recorded in the course of processing. The following yields were calculated: anatomic yield $\left(X_{2} / X_{1}\right)$, curing yield $\left(X_{3} / X_{2}\right)$, cooking yield $\left(X_{4} / X_{3}\right)$, technological yield $\left(X_{4} / X_{2}\right)$ and overall yield $\left(X_{4} / X_{1}\right)$.

\subsubsection{Eating quality}

The day after slaughter, three slices $(1 \mathrm{~cm}$ thick) were removed from the loin at the last rib level, vacuum-packed and stored at $-20{ }^{\circ} \mathrm{C}$ for about six months. Then, the frozen samples were thawed at $4^{\circ} \mathrm{C}$ for $24 \mathrm{~h}$, deboned and cooked on an electric grill for 4 min at $170^{\circ} \mathrm{C}$. In a total of 17 testing sessions, grilled chops were scored by a taste panel of 12 trained people for the following traits: visual compactness at cutting, tenderness, juiciness, mellowness and pork flavour intensity. Each descriptor was scored on a 10-point scale, from zero (very low) to 10 (very high).

\subsection{Statistical methods}

\subsubsection{Validation of prediction and comparison of the $R N$ genotypes}

In the course of the experiment, progeny tested animals from the segregant and tester populations have been selected considering their estimated RN genotype obtained from simple two-generation segregation analyses of RTN records, as described by Le Roy et al. [21]. Few errors were detected in the expected $\mathrm{rn}^{+} / \mathrm{rn}^{+}$genotyping of tester animals, suggesting possible misclassifications in founders. Considering all pedigree and RTN information collected in the design as a whole should improve the accuracy of RN genotype prediction. 
A second source of bias is inevitably expected from the selection of homozygous parents of the diallel cross: these animals were selected as extreme for the RN phenotype of their progeny test offspring, which should increase the differences in polygenic means between $\mathrm{RN}^{-} / \mathrm{RN}^{-}$and $\mathrm{rn}^{+} / \mathrm{rn}^{+}$selected parents. Analysing the genotypic effect of the diallel step animals without taking into account these phenomena could give an overestimation of the $\mathrm{RN}$ gene effects on RTN and correlated traits.

Guo and Thompson [13] proposed a pedigree analysis method which considers genealogy and performance records from the whole pedigree and thus makes a full use of available information for a single trait. The main feature of this method is the joint use of an EM algorithm and the Gibbs sampler for estimating the parameters of the mixed model of inheritance (major gene + polygenes). A more accurate genotyping of individuals can be expected from such a pedigree analysis as compared to the two-generation approach. Moreover, when records used for selection of parents are included in the analysis, a less biased estimation of parameters should be obtained, as far as the results found by Henderson [14] and others can be generalised to the mixed inheritance context.

The estimates of RN genotype effects on RTN were estimated from three approaches. The reference was the pedigree analysis with all RTN records described above. To evaluate the potential bias due to both genotype misclassification and selection of parents of the diallel cross, the two following simplified analyses were performed: a full pedigree analysis with the only diallel step RTN records; a classical mixed model (fixed + random effects), where the same genealogical information was used, but where the RTN of the last generation only was considered and RN genotypes were supposed to be known without error. The second approach did not consider the selection problem, the third approach did not neither consider the selection nor the misclassification problems. The complete pedigree starting from the founder animals chosen in Maxent comprised 1791 animals among which 1641 had a RTN record. All these data were considered in the reference pedigree analysis whereas only records of the 220 individuals of the diallel step were considered in the two simplified approaches. It was expected that, if little difference is found, the classical mixed model approach could provide a reliable estimates of the $\mathrm{RN}$ effects on all traits measured.

The Guo and Thompson [13] algorithm has been implemented in Fortran language with the following characteristics chosen after a number of trials: a dememorisation step of 100 Gibbs samples; 500 EM steps; a Monte Carlo sample size of 100; 20 Gibbs samples between two consecutive Monte Carlo samplings. More than $10^{6}$ samples have thus been generated. In order to increase mixing, the proposition of Janss et al. [15] for sampling of major genotypes has been retained: Gibbs sampling has been applied to the subvector of parents + final progenies (not having offspring) rather than to all individuals independently.

Three fixed effects have been included in the model, in accordance of their statistical significance in preliminary analyses of variance: sex (2 levels: female and castrated male), HAL genotype, determined using molecular genotyping [4] (2 levels: NN and Nn), and date of slaughter (107 levels). For any individual, the probability of each of the three RN genotypes was estimated by the mean, computed during the last EM step (100 samples), of this RN genotype 
probability conditional on the individual RTN value, the individual RTN polygenotype and the RN genotypes and RTN polygenotypes of other members of the pedigree (equation 9 of Guo and Thompson [13]). Inbreeding was taken into account in the relationship matrix and in the Gibbs sampling procedure.

\subsubsection{Estimation of $R N$ genotype effects}

Classical maximum likelihood analysis was performed using the PEST software [12]. Starting from the final generation of pigs, i.e. those recorded in the diallel step, pedigree was followed back up to the founders in order to constitute the pedigree file which contained 340 animals over 6 generations. The inbreeding option was used.

Traits were analysed in univariate models. The RN genotype of recorded individuals was supposed to be perfectly known and was considered as a fixed effect (3 levels: $\mathrm{RN}^{-} / \mathrm{RN}^{-}, \mathrm{RN}^{-} / \mathrm{rn}^{+}$and $\mathrm{rn}^{+} / \mathrm{rn}^{+}$). As stated above, three other fixed effects were included in the model: sex (2 levels), HAL genotype (2 levels) and environmental effect, i.e. date of biopsy for muscle GP (6 levels), fattening batch for growth and carcass composition traits (6 levels) and date of slaughter for meat quality traits (11 levels). Initial weight for average daily gain, live weight at biopsy for GP and live weight at slaughter for carcass and meat quality traits, were included as covariates. Litter effect and additive genetic value were considered as random effects. The corresponding variance components ( $\sigma_{c}^{2}$ and $\sigma_{a}^{2}$, respectively) could not be estimated from the present data due to the small size of data sets, and they were derived from average values of heritability $\left(h^{2}\right)$ and common litter environment $\left(c^{2}\right)$ reported in the literature [32]. The phenotypic variance $\sigma_{p}^{2}$ of each trait was estimated using the GLM procedure of SAS [31] and was set equal to the residual mean square of a fixed model analysis of variance including the same effects as those contained in the above-mentioned mixed models. Variance components were defined as $\sigma_{c}^{2}=c^{2} \sigma_{p}^{2} ; \sigma_{a}^{2}=h^{2} \sigma_{p}^{2}$ and $\sigma_{e}^{2}=\sigma_{p}^{2}-\sigma_{c}^{2}-\sigma_{a}^{2}$.

\section{RESULTS AND DISCUSSION}

\subsection{Validation of RN genotypes comparison}

Table II reports the predicted RN genotypes of progeny-tested animals using either full pedigree analysis or two-generation segregation analysis. In both approaches, a parent has been given a genotype $\mathrm{G}$ if the estimated probability of $G$ was higher than 0.80 . When none of the three possible genotypes had a probability higher than 0.80 , the genotype was considered as unknown (denoted "?").

With this threshold, few discrepancies were found between the two genotyping methods. One progeny-tested male was classified as $\mathrm{RN}^{-} / \mathrm{rn}^{+}$with the two-generation segregation analysis and as $\mathrm{rn}^{+} / \mathrm{rn}^{+}$with the pedigree analysis. The latter classification is consistent with his own low $\left(179 \mu \mathrm{mol} \cdot \mathrm{g}^{-1}\right)$ in vivo GP (not considered in the analyses). Regarding sows, three discrepancies were observed ( $1 \mathrm{RN}^{-} / \mathrm{rn}^{+}$changed to $\mathrm{RN}^{-} / \mathrm{RN}^{-}$and $2 \mathrm{rn}^{+} / \mathrm{rn}^{+}$from the tester line changed to $\left.\mathrm{RN}^{-} / \mathrm{rn}^{+}\right)$, without any clear explanation, except the fact that 
Table II. Distribution of breeding boars and sows according to their RN genotype as determined by either segregation analysis or pedigree analysis.

\begin{tabular}{|c|c|c|c|c|c|}
\hline \multirow{2}{*}{$\begin{array}{l}\text { Genotype } \\
\text { predicted from } \\
\text { pedigree analysis }\end{array}$} & \multicolumn{4}{|c|}{$\begin{array}{l}\text { Genotype predicted from two-generation } \\
\text { segregation analysis }\end{array}$} & \multirow[b]{2}{*}{ Total } \\
\hline & $\mathrm{RN}^{-} / \mathrm{RN}^{-}$ & $\mathrm{RN}^{-} / \mathrm{rn}^{+}$ & $\mathrm{rn}^{+} / \mathrm{rn}^{+}$ & $?$ & \\
\hline $\mathrm{RN}^{-} / \mathrm{RN}^{-}$ & 15 & 1 & 0 & 3 & 19 \\
\hline $\mathrm{RN}^{-} / \mathrm{rn}^{+}$ & 0 & 15 & 2 & 2 & 19 \\
\hline $\mathrm{rn}^{+} / \mathrm{rn}^{+}$ & 0 & 1 & 35 & 8 & 44 \\
\hline$?$ & 1 & 0 & 0 & 0 & 1 \\
\hline
\end{tabular}

they had a limited number of offspring (23, 6 and 11). Thirteen undetermined animals were more clearly genotyped with the pedigree approach. It should be emphasised that none of the boars and sows used as parents of the diallel-step offspring or of the resource families for linkage analyses showed a change in $\mathrm{RN}$ genotype in this retrospective study.

Based on the full pedigree approach, the RTN means were 83.2, 83.6 and $91.0 \%$ for $\mathrm{RN}^{-} / \mathrm{RN}^{-}, \mathrm{RN}^{-} / \mathrm{rn}^{+}$and $\mathrm{rn}^{+} / \mathrm{rn}^{+}$animals respectively, with a within-genotype standard deviation of 2.8. These figures confirm that the RN major gene is a dominant gene with a difference of 2.8 standard deviation (s.d.) units between means of homozygotes, an estimate very close to that found in the original study of Le Roy et al. [20] (2.9 s.d. units in the Laconie line). The within-major genotype heritability estimate was 0.46 in the present data set, to be compared with the estimate of 0.28 found by Le Roy et al. [20]. This increase in heritability is consistent with the expected better control of environment in the present experiment.

When the full pedigree approach was applied limiting the RTN information to the diallel step, the genotype means for RTN (in \%) were 82.2, 83.3 and 91.2 for $\mathrm{RN}^{-} / \mathrm{RN}^{-}, \mathrm{RN}^{-} / \mathrm{rn}^{+}$and $\mathrm{rn}^{+} / \mathrm{rn}^{+}$animals respectively. Based on the second simplified approach (classical animal model), the contrasts between genotype means for RTN, (in \%) were estimated as $-8.2 \pm 0.8$ and $-7.8 \pm 0.6$ for $\mathrm{RN}^{-} / \mathrm{RN}^{-}-\mathrm{rn}^{+} / \mathrm{rn}^{+}$and $\mathrm{RN}^{-} / \mathrm{rn}^{+}-\mathrm{rn}^{+} / \mathrm{rn}^{+}$, respectively, using the variance component estimates from the pedigree analysis $\left(\sigma_{p}=2.8 ; h^{2}=0.46\right)$. A bias, reaching about 5\%, was then probably due to the selection of parents of the diallel step, the estimates being close to those previously found [20]. Then, the diallel-step could be considered as a random sampling of RTN polygenes, allowing to estimate the $\mathrm{RN}$ gene effect on other recorded traits with a bias lower than $5 \%$.

In the following comparisons, the PEST software was used and both litter and additive genetic random effects were taken into account in the model of analysis, genetic parameters being set to classically accepted values. With that method, the same two contrasts between genotype means for RTN were estimated as $-8.4 \pm 0.7$ and $-7.8 \pm 0.6$ with a within-genotype standard deviation being equal to 2.6 and $h^{2}$ and $c^{2}$ coefficients being set to 0.30 and 0.05 , respectively. Several tests showed that the estimates of RN genotype means for RTN are quite robust to variation in parameters $h^{2}$ and $c^{2}$. 


\subsection{Estimation of $\mathrm{RN}$ genotype effects}

Tables III to VII give results of the RN genotype comparison. Only contrasts between genotypic means can be estimated without bias, and results are presented relative to the control $\mathrm{rn}^{+} / \mathrm{rn}^{+}$genotype $\left(\mu_{\mathrm{RN}^{-} / \mathrm{RN}^{-}}-\mu_{\mathrm{rn}^{+} / \mathrm{rn}^{+}}\right.$ and $\mu_{\mathrm{RN}^{-} / \mathrm{rn}^{+}}-\mu_{\mathrm{rn}}{ } / \mathrm{rn}^{+}$contrasts $)$. Least squares means for the $\mathrm{rn}^{+} / \mathrm{rn}^{+}$ genotype $\left(\mu_{\mathrm{rn}}+/ \mathrm{rn}^{+}\right)$, and the within-genotype standard deviations $\left(\sigma_{p}\right)$, as computed by the SAS GLM procedure, are also given. For each trait, both tests of significance of the RN genotype effect (test of the " $\mu_{\mathrm{RN}^{-}} / \mathrm{RN}^{-}-\mu_{\mathrm{rn}^{+} / \mathrm{rn}^{+}}=0$ and $\mu_{\mathrm{RN}^{-}} / \mathrm{rn}^{+}-\mu_{\mathrm{rn}^{+} / \mathrm{rn}^{+}}=0$ " hypothesis) and of the dominance effect (test of the " $d=0$ " hypothesis, with $\left.d=\mu_{\mathrm{RN}^{-} / \mathrm{rn}^{+}}-0.5\left(\mu_{\mathrm{RN}^{-} / \mathrm{RN}^{-}}+\mu_{\mathrm{rn}^{+} / \mathrm{rn}^{+}}\right)\right)$are shown.

\subsubsection{Growth performance}

Estimated effects of the RN genotype on growth traits (Tab. III) did not significantly differ from 0, except for average daily gain. For this trait, the heterozygote $\mathrm{RN}^{-} / \mathrm{rn}^{+}$had a significant advantage over the two homozygous genotypes which were very close to each other. The dominance effect was highly significant $(P<0.01)$ and was estimated as $42 \mathrm{~g} \cdot$ day $^{-1}$, i.e. one half of the phenotypic standard deviation of the trait. Such a situation of over dominance is fairly surprising, but it should be mentioned that a favourable effect of the $\mathrm{RN}^{-}$allele on daily gain was also found by Enfält et al. [7] comparing $\mathrm{RN}^{-} / \mathrm{rn}^{+}$ and $\mathrm{rn}^{+} / \mathrm{rn}^{+}$animals.

\subsubsection{Carcass composition}

Effects of the RN genotype on carcass composition traits are given in Table IV. There was no RN genotype effect on killing out percentage or carcass compactness, but $\mathrm{RN}^{-} / \mathrm{RN}^{-}$animals were longer than $\mathrm{RN}^{-} / \mathrm{rn}^{+}$and $\mathrm{rn}^{+} / \mathrm{rn}^{+}$ pigs. These results are agree with those of Enfält et al. [7] and Reinsch et al. [30] which found no difference between $\mathrm{RN}^{-} / \mathrm{rn}^{+}$and $\mathrm{rn}^{+} / \mathrm{rn}^{+}$animals for these traits.

On the whole, variables pertaining to carcass tissue composition showed that the $\mathrm{RN}^{-}$allele is associated with leaner carcasses. Except for the measurement at the shoulder, back fat thickness was decreased by about 1 s.d. in homozygous carriers $\mathrm{RN}^{-} / \mathrm{RN}^{-}$, heterozygotes being intermediate between the two homozygotes and the dominance effect being very close to 0 . Concerning the weight of carcass joints, the same trend was observed, with a significant increase in weight of lean joints (ham and loin) and a concomitant, though smaller, decrease of weight of fat joints (belly, back fat and leaf fat). However, the estimated RN effect was lower than for backfat thickness, with differences of only about 0.5 s.d. between means of the two homozygotes. Furthermore, the dominance effect was generally significant, and the heterozygous and homozygous carriers were not different. Consequently, carcass lean content was increased by about 0.75 s.d. in $\mathrm{RN}^{-}$carriers with a situation of complete dominance. Loin eye area, measured only on a subsample of animals, followed a similar pattern. 


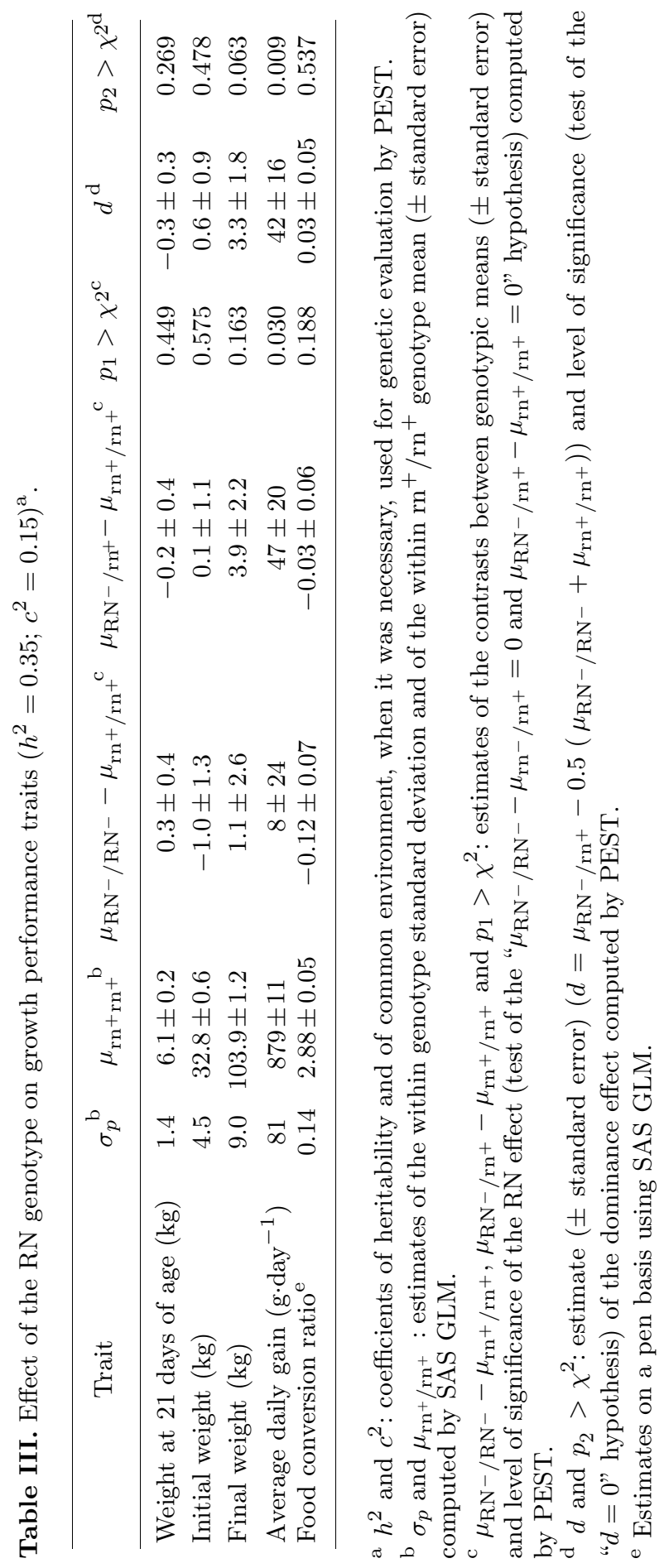



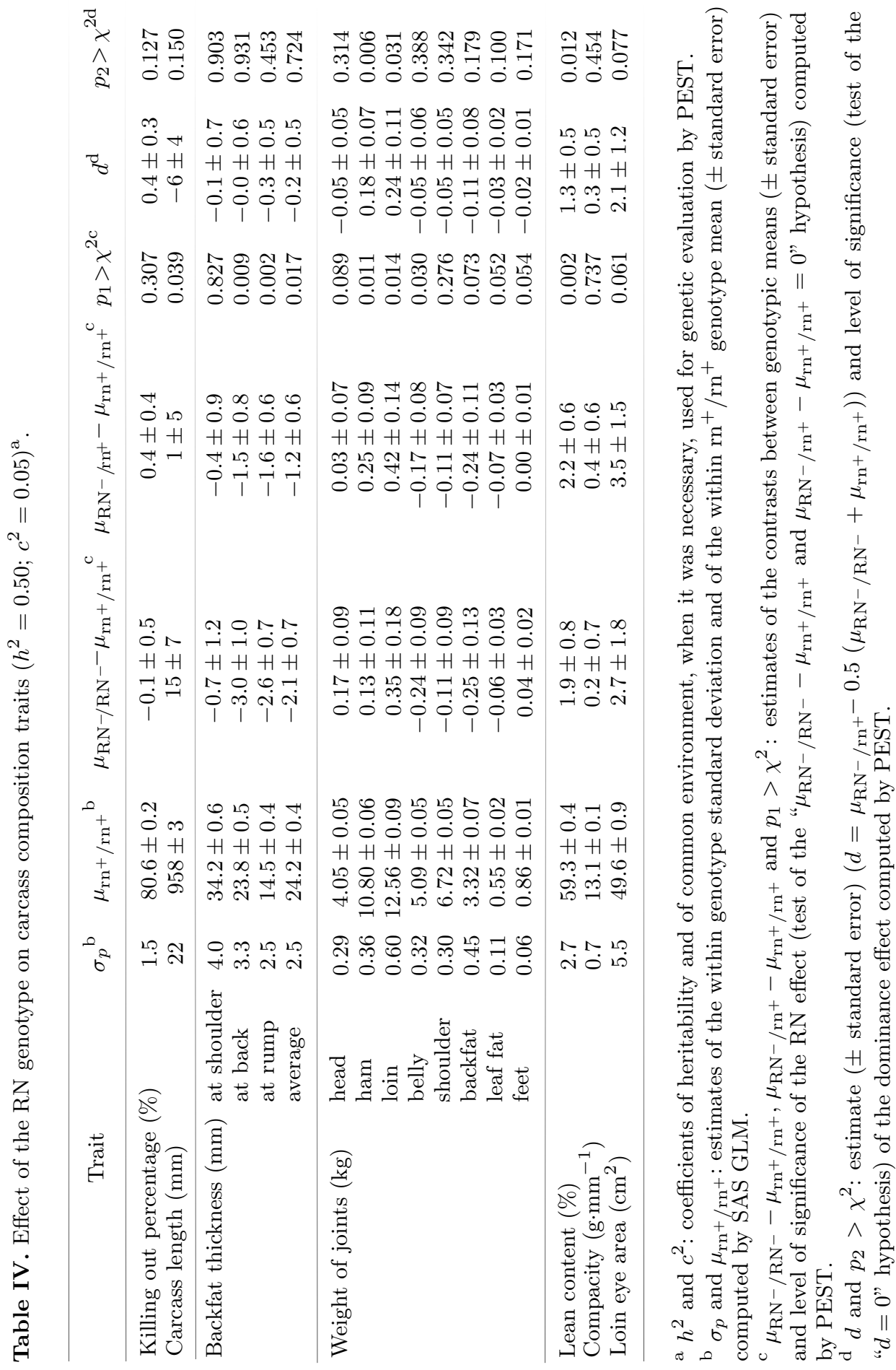
That carcass lean meat content is higher in $\mathrm{RN}^{-}$carriers than in $\mathrm{RN}^{-}$noncarriers has been consistently reported $[7,23,30]$. However, an effect of the RN gene on backfat thickness was only found in the present study, i.e. the only one including the homozygous $\mathrm{RN}^{-} / \mathrm{RN}^{-}$genotype. Dominance relationships for backfat thickness (additivity of alleles) differed from those for lean meat content or weights of joints (complete dominance of $\mathrm{RN}^{-}$over $\mathrm{rn}^{+}$). This could probably be explained by the $\mathrm{RN}$ effect on carcass length. Indeed, $\mathrm{RN}^{-} / \mathrm{RN}^{-}$ animals were longer but with lower backfat thickness when compared with $\mathrm{RN}^{-} / \mathrm{rn}^{+}$animals, which resulted in the same weight of backfat for both carrier genotypes.

The favourable effect of $\mathrm{RN}^{-}$on carcass lean to fat ratio is in accordance with the positive genetic correlation of lean to fat ratio with muscle GP found by Larzul et al. [18] in a presumably $\mathrm{RN}^{-}$-free population. Higher muscle GP appears to be genetically associated with leaner carcass regardless of whether the increase in GP is due to the $\mathrm{RN}^{-}$allele or to polygenes.

\subsubsection{Muscle glycolytic potential}

Results concerning the muscle GP measured in vivo (I.V.) and post mortem (P.M.), are presented in Table V. All variables pertaining to GP and its components, except the PM lactate concentration in the longissimus muscle, were very strongly affected by the RN genotype. In longissimus muscle GP, the difference between homozygotes reached 6.85 s.d. in vivo but "only" 3.45 s.d. post mortem. On the other hand, this difference was lower when the measured muscle was more oxidative, i.e. 3.45 s.d. in the longissimus, 3.09 s.d. in the semimembranosus and 1.09 s.d. in the semispinalis capitis muscle. Regarding the muscle GP, the effect of dominance of $\mathrm{RN}^{-}$over $\mathrm{rn}^{+}$was significant in the longissimus and semimembranosus muscles and close to significance in the semispinalis capitis muscle. The $\mathrm{RN}^{-} / \mathrm{rn}^{+}$pigs did not significantly differ from the $\mathrm{RN}^{-} / \mathrm{RN}^{-}$pigs in GP of the semimembranosus and semispinalis capitis muscle whereas the $\mathrm{RN}^{-} / \mathrm{rn}^{+}$pigs showed significantly lower IVGP and PMGP values than the $\mathrm{RN}^{-} / \mathrm{RN}^{-}$pigs in longissimus muscle.

Regarding the components of muscle PMGP, the effect of $\mathrm{RN}^{-}$on residual glycogen was larger in the "white" longissimus and semimembranosus muscles than in the "red" semispinalis capitis muscle. The two "white" muscles somehow differed regarding the effect of $\mathrm{RN}^{-}$on $\mathrm{PM}$ lactate concentration: there was no effect of $\mathrm{RN}^{-}$(and even a slightly negative effect) in the longissimus muscle whereas the overall effect of $\mathrm{RN}^{-}$was positive in the semimembranosus muscle.

All these results showed that the primary effect of the RN gene is certainly to increase muscle GP. As stated above, this widely accepted hypothesis had never been properly demonstrated. Here, the RN genotypes being established from RTN measurements, the identity between the "RN gene effect" and the "Hampshire effect" is clearly proven. Furthermore, all previous studies on the $\mathrm{RN}$ gene effects did not consider the homozygous genotype $\mathrm{RN}^{-} / \mathrm{RN}^{-}$and so could not estimate the effect of dominance. The dominance of the $\mathrm{RN}^{-}$allele for muscle GP can be assumed to be complete in the semimembranosus and semispinalis capitis muscles and almost complete in the longissimus muscle. 
Effects of the RN gene in pigs

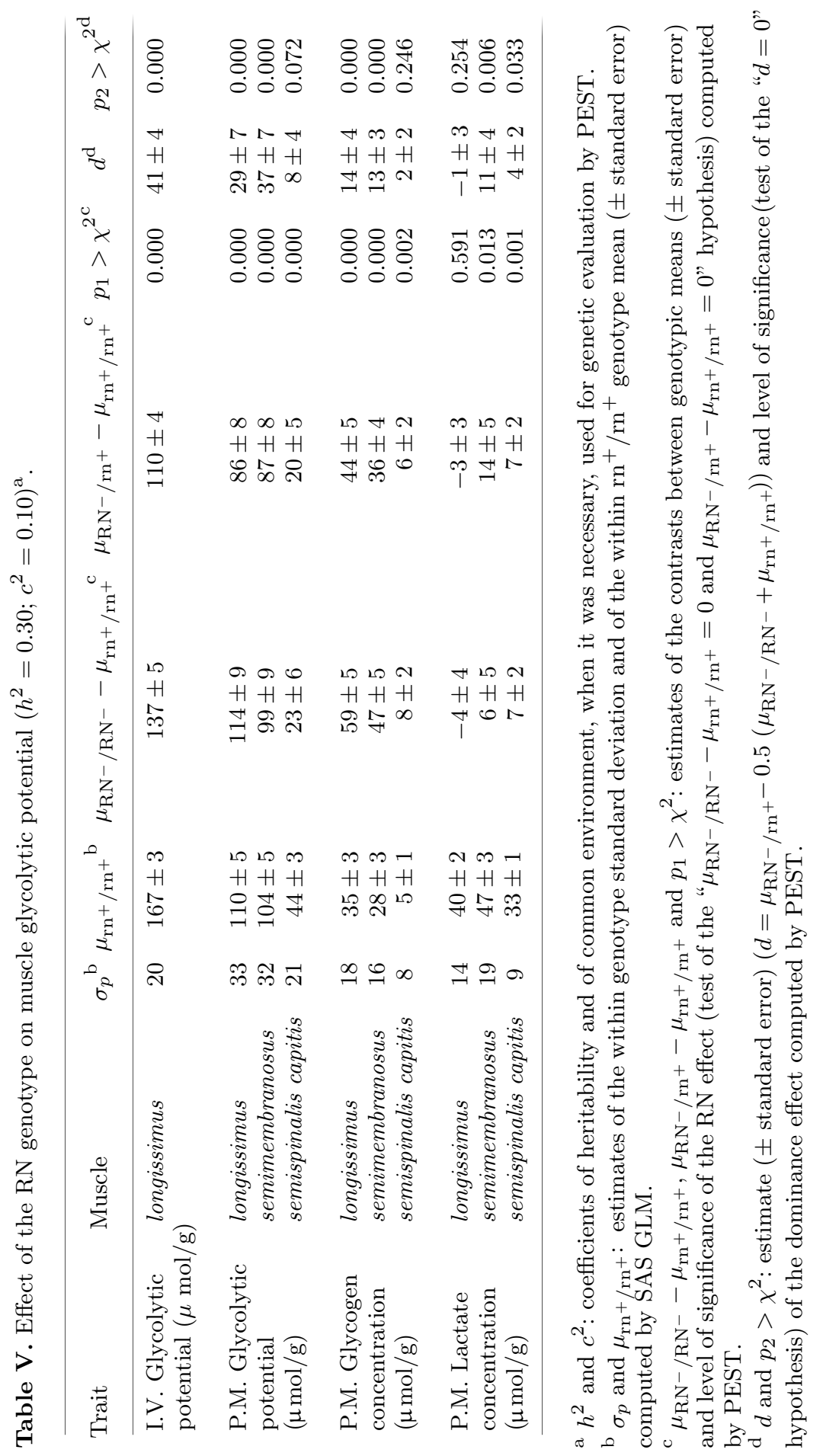




\subsubsection{Physico-chemical characteristics of muscle}

The effects of the RN gene on physico-chemical characteristics of muscle are reported in Table VI. The RN genotype had no effect on longissimus $\mathrm{pH}_{1}$ but, as expected, had a major effect of about 2 s.d. on $\mathrm{pH}_{24}$ of all studied muscles. Furthermore, for the latter trait, the $\mathrm{RN}^{-}$allele appeared to be fully dominant, confirming the non-linear relationship between GP (either I.V. or P.M.) and ultimate $\mathrm{pH}$, with a threshold value of GP beyond which ultimate $\mathrm{pH}$ is constant (for review, see [17]).

Effects of RN were also highly significant for most meat colour parameters. The lightness $L^{*}$ parameter was increased in $\mathrm{RN}^{-}$carriers by about 0.8 s.d., except for the biceps femoris in the $\mathrm{RN}^{-} / \mathrm{rn}^{+}$genotype, which corresponds to a paler meat. Regarding effects of $\mathrm{RN}$ on redness and yellowness, an overdominance situation was encountered, $a^{*}$ and $b^{*}$ parameters being higher in the heterozygous genotype. Finally, water-holding capacity was decreased in the longissimus muscle of the $\mathrm{RN}^{-}$carriers, and there was a similar, but not significant, tendency for the two other muscles studied.

On the whole, preceding hypotheses $[7,22,23,30,33]$ concerning the implication of the RN gene in the occurrence of the "Hampshire effect" are fully supported by these new observations. On the other hand, the present comparison including homozygous carrier animals allows confirmation of the complete dominance of the $\mathrm{RN}^{-}$allele for most physico-chemical characteristics of meat, e.g. $\mathrm{pH}_{24}$ and colour ( $L^{*}$ value).

\subsubsection{Technological and eating meat quality}

As shown in Table VII, most technological and eating meat quality traits were affected by the RN genotype. The estimated difference between homozygotes for Napole yield was 8.4 percentage points (3.2 s.d.), i.e. a value fairly similar to that obtained in the primary study of Le Roy et al. [20]. A difference of around 6 percentage points in Napole yield was reported by Lundström et al. [24] comparing $\mathrm{RN}^{-} / \mathrm{rn}^{+}$and $\mathrm{rn}^{+} / \mathrm{rn}^{+}$offspring.

Except for the anatomic yield, the yields measured during the curedcooked ham processing were lower in the $\mathrm{RN}^{-}$carriers. This decrease was not significant for curing yield, but was highly significant for cooking, technological and overall yields. The difference between homozygotes reached 1.5 s.d. for cooking yield and 1.1 s.d. for technological yield. The $\mathrm{RN}^{-}$allele appeared to be completely dominant over the $\mathrm{rn}^{+}$allele for these traits.

The adverse effect of $\mathrm{RN}^{-}$was of much smaller magnitude for technological yield of cured-cooked ham processing (around 2 percentage points) than for Napole yield ( 8 percentage points). This is probably related to the peculiar ham processing method used in the present experiment. The process included several phases of tumbling of meat during the curing step resulting in a high average for weight gain at curing (8-9\%) and low average values for weight loss during cooking (5-6\%). One can assume that such a process led to weakening the differences between RN genotypes. For comparison, Lundström et al. [24], using a similar ham processing method but without tumbling, found an advantage of around 4 percentage points in processing yield for $\mathrm{rn}^{+} / \mathrm{rn}^{+}$pigs $(84.9 \%)$, compared with $\mathrm{RN}^{-} / \mathrm{rn}^{+}$pigs $(80.8 \%)$. 


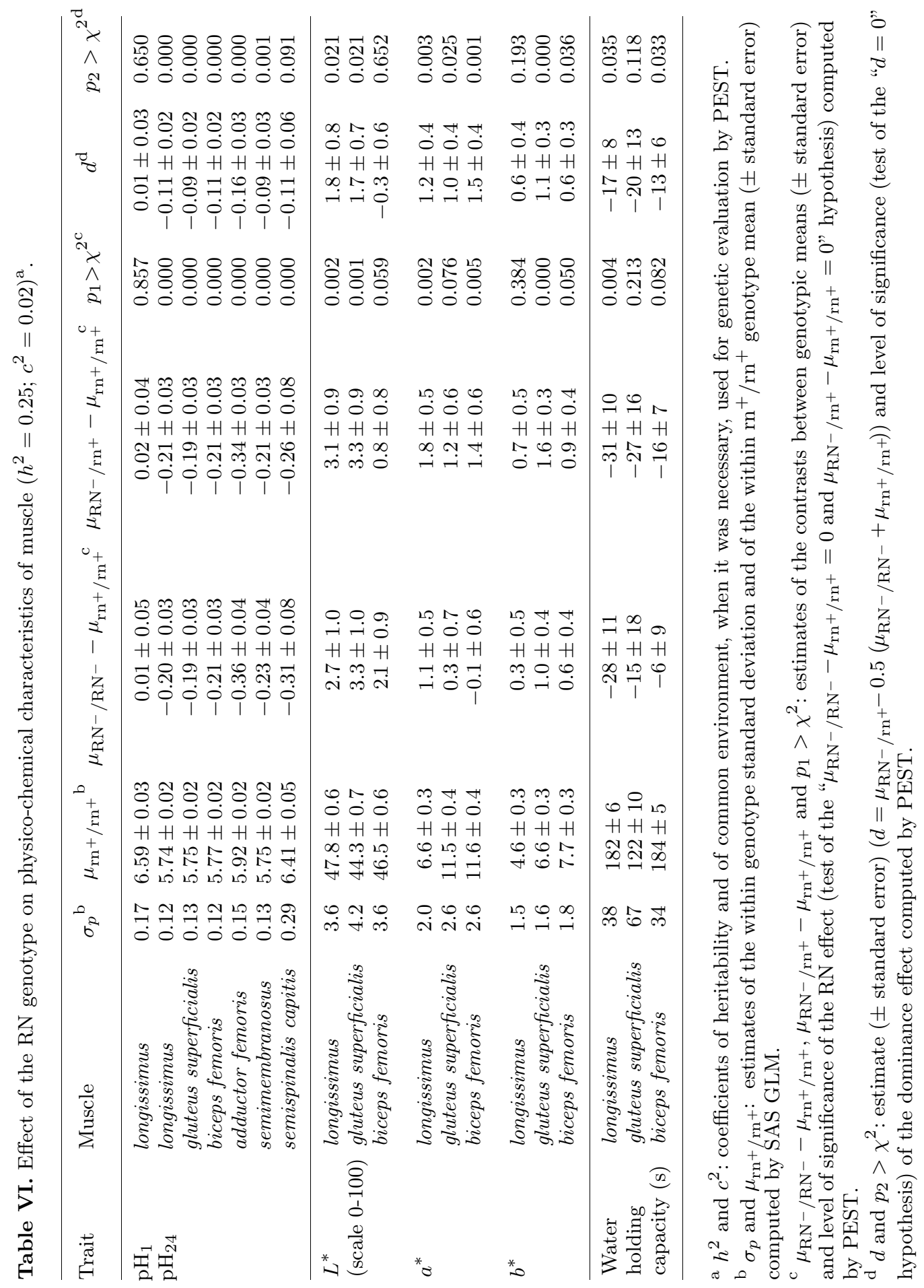




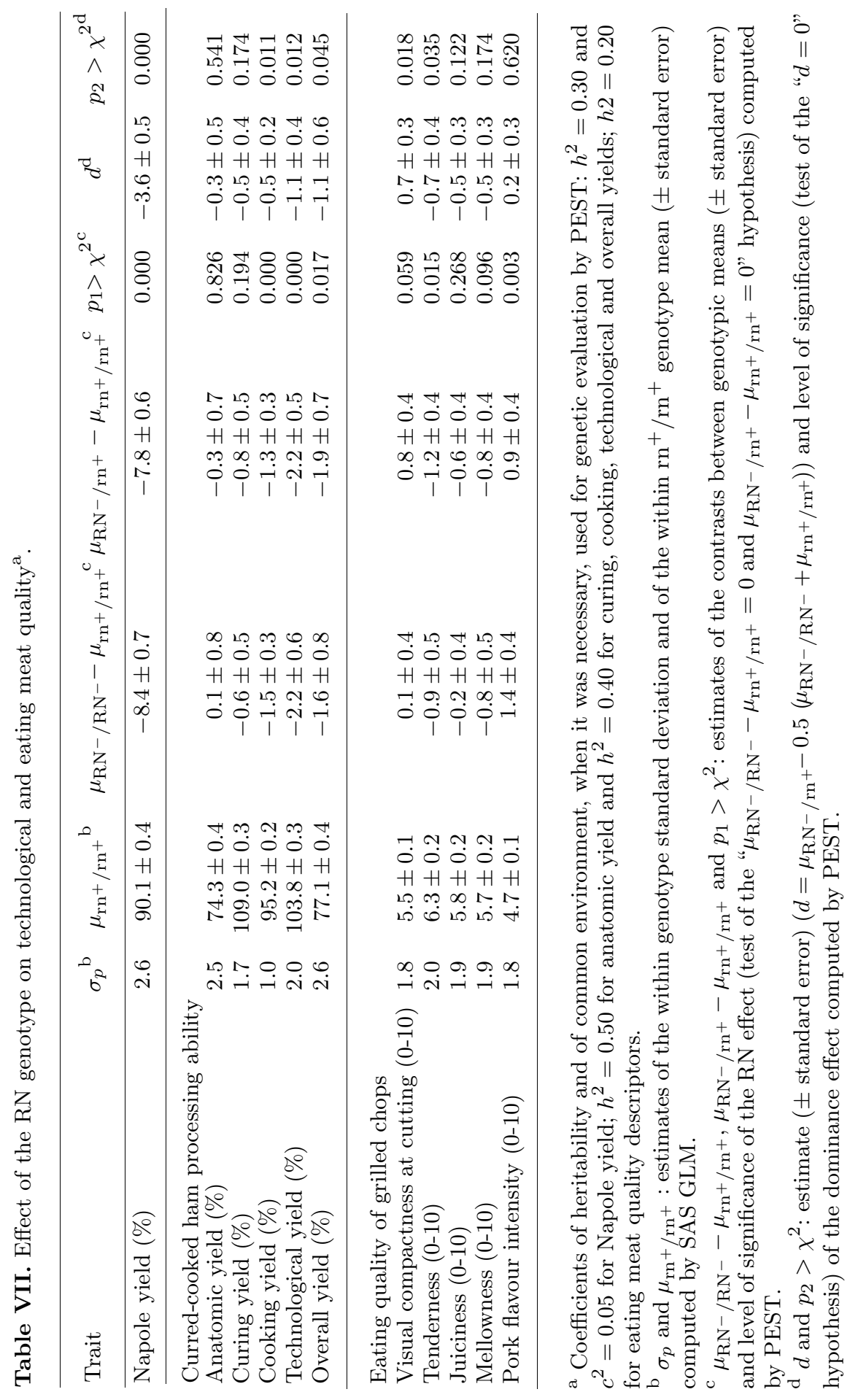


Some of the eating quality traits were also influenced by the RN gene. Score for tenderness was lower in the $\mathrm{RN}^{-}$carriers while these animals exhibited pork flavour intensity. The $\mathrm{RN}^{-} / \mathrm{RN}^{-}$and $\mathrm{RN}^{-} / \mathrm{rn}^{+}$were close to each other for tenderness. The gene effect on flavour was approximately additive. Lundström et al. [23] found also a superiority of $\mathrm{RN}^{-}$carriers for meat taste and smell intensities. However, opposite to our results, no difference between $\mathrm{RN}^{-} / \mathrm{rn}^{+}$ and $\mathrm{rn}^{+} / \mathrm{rn}^{+}$animals was found for tenderness in Swedish studies and a slight decrease of shear force [23] or chewing time [24] was even shown by $\mathrm{RN}^{-}$ carriers. This discrepancy could be explained by difference in the variability of QTL linked to the RN gene between the two experiments: the observed effect on tenderness of meat is perhaps not a pleiotropic effect of the RN gene but an effect of one or several loci closely linked to RN.

\section{CONCLUSION}

Numerical comparison between estimates, given either by full pedigree analysis or by simpler analysis of the diallel design considering offspring genotypes as fixed effects, supported the hypothesis that the parents used in diallel matings were correctly genotyped and sampled, as regards their polygenic value. A fortiori, estimates of RN genotype effect on RTN-correlated (or non-correlated) traits may be considered as only slightly biased (less than $5 \%$ ) by miss-genotyping or selection influence. In the present article, RN effects have thus been evaluated from the performance records of the diallel offspring only, using "classical" animal model procedures.

This study definitely confirms that the porcine RN gene has considerable effects on muscle glycolytic potential and some GP-related traits. When expressed in standard deviation unit of the trait, the effect of $\mathrm{RN}$ on GP of longissimus muscle is found to be comparable in magnitude with the largest single-gene effects currently known in animals, e.g. dwarfing genes in mouse and chickens, the muscle hypertrophy gene in cattle and the "Booroola" gene in sheep. The identity between the acid meat characteristics and the $\mathrm{RN}^{-}$allele effect is clearly demonstrated. The main features of the "Hampshire" effect were observed in $\mathrm{RN}^{-}$carrier animals: higher muscle GP, lower ultimate $\mathrm{pH}$, paler meat and lower protein content. Moreover, our results are fully consistent with those previously obtained from comparing "high GP" and "low GP" Hampshire-cross pigs even though one discrepancy was noted for tenderness of meat. Furthermore the present comparison between the three RN genotypes allowed to confirm the complete dominance of the $\mathrm{RN}^{-}$allele for RTN, and most meat quality traits. However, the dominance was not quite complete for IVGP which is probably the primary trait affected by the RN gene. Finally, the relationship between GP and carcass lean to fat ratio was confirmed here in the frame of the RN gene segregation. This association could arise either from a pleiotropic effect of the RN gene itself or from effects of other loci located close to $\mathrm{RN}$ and in linkage disequilibrium with $\mathrm{RN}$ in the present population of sires. 


\section{ACKNOWLEDGEMENTS}

This work was part of the project "Régulation du potentiel glycolytique du muscle chez le porc" and was supported by grants from the INRA-Agrobio program. The authors acknowledge Y. Billon (INRA, Domaine du Magneraud) and the staff of the pig experimental unit in Le Magneraud, H. Lagant (INRA, Station de génétique quantitative et appliquée) and P. Vernin (INRA, Station de recherches sur la viande) for their technical assistance.

\section{REFERENCES}

[1] Anonymous, Résultats du $16^{\mathrm{e}}$ test d'évaluation des performances de croissance, de composition corporelle et de qualité de la viande des produits terminaux des schémas de sélection et croisement, Techni-porc 13 (1990) 29-45.

[2] Bergmeyer H.U., in: Bourne G.H. (Ed.), Methods of enzymatic analysis, Academic Press, New York, 1974, pp. 1127-1196.

[3] Charpentier J., Monin G., Ollivier L., Correlations between carcass characteristics and meat quality in Large White pigs, in: Proceedings of the 2nd International Symposium on Condition and Meat Quality of Pigs, Pudoc, Wageningen, 1971, pp. 255-260.

[4] Dalens M., Runavot J.P., Test moléculaire pour le dépistage du gène de la sensibilité à l'halothane chez le porc, Techni-porc 16 (1993) 17-20.

[5] Dalrymple R.H., Hamm R., A method for the extraction of glycogen and metabolites from a single muscle sample, J. Food Technol. 8 (1973) 439-444.

[6] Elsen J.M., Le Roy P., Simplified versions of segregation analysis for detection of major genes in animal breeding data, in: Book Abstr. of the 40th EAAP Ann. Meeting, Dublin, Ireland, 1989, vol.1, pp. 57-58.

[7] Enfält A.C., Lundström K., Hansson I., Johansen S., Nyström P.E., Comparison of non-carriers and heterozygous carriers of the $\mathrm{RN}^{-}$allele for carcass composition, muscle distribution and technological meat quality in Hampshire-sired pigs, Livest. Prod. Sci. 47 (1997) 221-229.

[8] Estrade M., Vignon X., Monin G., Effect of the $\mathrm{RN}^{-}$gene on ultrastructure and protein fractions in pig muscle, Meat Sci. 35 (1993) 313-319.

[9] Estrade M., Vignon X., Rock E., Monin G., Glycogen hyperaccumulation in white muscle fibres of $\mathrm{RN}^{-}$carrier pigs. A biochemical and ultrastructural study, Comp. Biochem. Physiol. 104B (1993) 321-326.

[10] Estrade M., Ayoub S., Talmant A., Monin G., Enzyme activities of glygogen metabolism and mitochondrial characteristics in muscles of $\mathrm{RN}^{-}$carrier pigs (Sus scrofa domesticus), Comp. Biochem. Physiol. 108B (1994) 295-301.

[11] Fernandez X., Lefaucheur L., Guéblez R., Monin G., Paris ham processing: technological yield as affected by residual glycogen content of muscle, Meat Sci. 29 (1991) 121-128.

[12] Groeneveld E., Kovac M., A generalized computing procedure for setting up and solving mixed linear models, J. Dairy Sci. 73 (1990) 513-531.

[13] Guo S.W., Thompson E.A., Monte Carlo estimation of mixed models for large complex pedigrees, Biometrics 50 (1994) 417-432.

[14] Henderson C.R., Comparison of alternative sire evaluation methods, J. Anim. Sci. 41 (1975) 760-770.

[15] Janss L.L.G., Thompson R., van Arendonk J.A.M., Application of Gibbs sampling for inference in a mixed major gene-polygenic inheritance model in animal populations, Theor. Appl. Genet. 91 (1995) 1137-1147. 
[16] Laborde D., Talmant A., Monin G., Activités enzymatiques métaboliques et contractiles de 30 muscles du porc. Relations avec le $\mathrm{pH}$ ultime atteint après la mort, Reprod. Nutr. Dév. 25 (1985) 619-628.

[17] Larzul C., Le Roy P., Monin G., Sellier P., Variabilité génétique du potentiel glycolytique du muscle chez le porc, INRA Prod. Anim. 11 (1998) 183-197.

[18] Larzul C., Le Roy P., Gogué J., Talmant A., Monin G., Sellier P., Selection for reduced muscle glycolytic potential in Large White pigs. III. Correlated responses in growth rate, carcass composition and reproductive traits, Genet. Sel. Evol. 31 (1999) 149-161.

[19] Lebret B., Le Roy P., Monin G., Lefaucheur L., Caritez J.C., Talmant A., Elsen J.M., Sellier P., Influence of the three RN genotypes on chemical composition, enzyme activities, and myofiber characteristics of porcine skeletal muscle, J. Anim. Sci. 77 (1999) 1482-1489.

[20] Le Roy P., Naveau J., Elsen J.M., Sellier P., Evidence for a new major gene influencing meat quality in pigs, Genet. Res. 55 (1990) 33-40.

[21] Le Roy P., Caritez J.C., Elsen J.M., Sellier P., Pigmeat quality: experimental study on the RN major locus, in: Proceedings of the 5th World Congress on Genetics Applied to Livestock Production, University of Guelph, Canada, 1994, vol. 19 , pp. $473-476$.

[22] Le Roy P., Przybylski W., Burlot T., Bazin C., Lagant H., Monin G., Etude des relations entre le potentiel glycolytique du muscle et les caractères de production dans les lignées Laconie et Penshire, in: $26^{\mathrm{e}}$ Journées de la recherche porcine en France, Institut technique du porc, Paris, France, 1994, pp. 311-314.

[23] Lundström K., Andersson A., Hansson I., Effect of the RN gene on technological and sensory meat quality in crossbred pigs with Hampshire as terminal sire, Meat Sci. 42 (1996) 145-153.

[24] Lundström K., Enfält A.C., Tornberg E., Agerhem H., Sensory and technological meat quality in carriers and non-carriers of the $\mathrm{RN}^{-}$allele in Hampshire crosses and in purebred Yorkshire pigs, Meat Sci. 48 (1998) 115-124.

[25] Milan D., Le Roy P., Woloszyn N., Caritez J.C., Elsen J.M., Sellier P., Gellin J., The RN locus for meat quality maps to pig chromosome 15, Genet. Sel. Evol. 27 (1995) 195-199.

[26] Monin G., Sellier P., Pork of low technological quality with a normal rate of muscle $\mathrm{pH}$ fall in the immediate post-mortem period: the case of the Hampshire breed, Meat Sci. 13 (1985) 49-63.

[27] Monin G., Mejenes-Quijano A., Talmant A., Sellier P., Influence of breed and muscle metabolic type on muscle glycolytic potential and meat $\mathrm{pH}$ in pigs, Meat Sci. 20 (1987) 149-158.

[28] Naveau J., Contribution à l'étude du déterminisme génétique de la qualité de la viande porcine. Héritabilité du rendement technologique Napole, in: $18^{\mathrm{e}}$ Journées de la recherche porcine en France, Institut technique du porc, Paris, France, 1986, pp. $265-276$.

[29] Naveau J., Pommeret P., Lechaux P., Proposition d'une méthode de mesure du rendement technologique : la "méthode Napole", Techni-porc 8 (6) (1985) 7-13.

[30] Reinsch N., Looft C., Rudat I., Kalm E., Is the porcine RN locus a pleiotropic QTL? A Bayesian marker assisted segregation analysis, Genet. Sel. Evol. 30 (1998) $257-273$.

[31] $\mathrm{SAS}^{\circledR}, \mathrm{SAS}^{\circledR}$ Inst. Inc., Cary, NC, 1985.

[32] Sellier P., Genetics of meat and carcass traits, in: Rothschild M.F., Ruvinsky A. (Eds), The genetics of the pig, CAB International, Wallingford, Oxon, United Kingdom, 1998, pp. 463-510.

[33] Sellier P., Monin G., Genetics of pig meat quality: a review, J. Muscle Foods 5 (1994) 187-219. 
[34] Talmant A., Fernandez X., Sellier P., Monin G., Glycolytic potential in Longissimus dorsi muscle of Large White pigs as measured after in vivo sampling, in: Proceedings of the 35th International Congress on Meat Science and Technology, Roskilde, Denmark, 1989, pp. 1129-1132.

[35] Wassmuth R., Surmann H., Glodek P., Untersuchungen zum "Hampshirefaktor" in der Fleischbeschaffenheit von Schweinen, Züchtungskunde 63 (1991) 445-455. 